\title{
A Possible Cause of the Siberian LIPs: "Collisions Aggrgation Effect" of an Aerolite Impact
}

\author{
Liu Chenming, Yang Demin
}

Resource Exploration Institute, Yunnan Land and Resources Vocational College, Kunming, China

\section{Email address:}

xiao6yu2000@aliyun.com(Liu Chenming)

\section{To cite this article:}

Liu Chenming, Yang Demin. A Possible Cause of the Siberian LIPs: "Collisions Aggrgation Effect" of an Aerolite Impact. Earth Sciences. Vol. 7, No. 3, 2018, pp. 98-106. doi: 10.11648/j.earth.20180703.12

Received: February 8, 2018; Accepted: March 10, 2018; Published: April 9, 2018

\begin{abstract}
The authors believe that the main reason for the formation of the Siberian LIPs may be the nonlinear "Collisions Aggregation Effect" caused by a meteorite impact in the Falkland Plateau crater or Wilkes Land crater, and the correspondence of the Falkland Plateau crater may be better. As a result, the authors have reached the following conclusions and understandings: 1 . The late Permian: the siberian LIPs are in the Siberian plate at $60^{\circ} \mathrm{N}, 80^{\circ} \mathrm{E}$; the Falkland Plateau crater is located in the southwestern corner of the Gondwana, about at $70^{\circ} \mathrm{S}, 30^{\circ} \mathrm{E}$, at the southernmost point of the South American plates, close to the southern orogenic belt of the South America and the stress state of the Falkland Plateau crater may be under pressure; the Wilkes Land crater may be located at $60^{\circ} \mathrm{S}, 110^{\circ} \mathrm{E}$, at the eastern Antarctic continent, close to the Australian plate, is not located in the orogenic belt and the stress state of the Wilkes Land crater should not be pressure-type, but is in a wide range of ice covered area; 2. Figure 6 and 7 show the location relationship between the Siberian LIPs and Falkland Plateau crater or Wilkes Land crater does not have a antipodal characteristic, nor have a linear "Collisions Aggregation Effect" profile, but have a nonlinear "Collisions Aggregation Effect" distribution, the Falkland Plateau crater correspondence may be better; 3. Whether or not the Falkland Plateau crater or Wilkes Land crater was finally confirmed as a true meteorite crater, their relationships with the Siberian LIPs should have a nonlinear distribution of "Collisions Aggregation Effect" when the time they formed close to the Siberian LIPs, and is the main reason for the formation of the Siberian LIPs. The velocity vector direction of the meteorite impact may have a smaller angle of impact, and significantly eastward (relative to the Earth's center); 4. About the celestial body which its impact can form LIPs or cause the formation of LIPs, it should have: the impact time should be earlier than LIPs or almost simultaneously; a certain size; the "impact point" and the LIPs distribution area have the "Collisions Aggregation Effect" distribution characteristics; 5 . Figure 2 shows a possible formation model about LIPs of a celestial body collision: due to the violent impact of a celestial body, created a tectonic weakness in the crust, even up to the crust-mantle boundary, a fault zone pointing to the Earth's center, and a radial spherical fracture group at the "impact point" or "collisions aggregation point"; the magma originating from the mantle intrude along the weak zone under pressure, a large number of magma invaded and gathered in the radial spherical fracture group, causing the overlying strata rising slowly, forming a dome and a similar head-tail structure of the mantle plume that the head dilated, tail slender deep into the mantle on the longitudinal.
\end{abstract}

Keywords: Siberian LIPs, Falkland Plateau Crater, Wilkes Land Crater, Collisions Aggregation Effect, Aerolite Impact, Palaeogeography

\section{Introduction}

\subsection{Research Background}

In the history of the Earth, there have been many meteorite impact events [1]. With the progress of the Earth science and the development of science and technology, the craters from these meteorites and the timing and location are gradually discovered and recognized by human beings. The oldest crater can be traced to more than two billion years [2], young only ten years [3]. In recent years, many scholars associate the meteorite impact events, LIPs, extinction of organisms, and the Plate division in the hope of discovering laws and interpreting some geological events [4-10]. The author has discussed the causes of the Emeishan LIPs in China and the possible paleogeographic location of the "impact point" [4-6]. 
In addition, some research work has been done on the relationship between the Deccan LIPs and the Chicxulub Crater, and enriched the content of "Collisions Aggregation Effect", proposed the linear "Collisions Aggregation Effect" and the nonlinear "Collisions Aggregation Effect" [7]. As the world-famous large igneous province-Siberian LIPs, many scholars have conducted research on it [9-15]. Von Foster [9] argues that the Siberian LIPs were caused by a volcanic activity from a meteorite impact that occurred on the antipodes in the Antarctic at the end of the Permian, but there is still some doubt about the existence of the meteorite impact in the Antarctic [16]. Michael et al. [17-18] reported that a crater with a diameter of over $250 \mathrm{~km}$ was found under the Falkland (Malvinas) near the waters of the South Atlantic near Argentina, and there was a large amount of evidence data based on geophysics, and is consistent with the formation of the Siberian LIPs at about 250 Ma [13]. It should be emphasized that neither the Wilkes Land crater nor Falkland Plateau crater is located on the antipodes of the Siberian LIPs at about $250 \mathrm{Ma}$. Based on the current research findings and the Late Permian global paleogeographic data, according to the "Collisions Aggregation Effect", the author put forwards that the main reason for the formation of the Siberian LIPs may be the nonlinear "Collisions Aggregation Effect" caused by the meteorite impact of the Falkland Plateau crater or Wilkes Land crater.

\subsection{Siberian LIPS (SLIP)}

The Siberian LIPs (SLIP) spans the Siberian Craton and
West Siberia Basins (Figure. 1) [11], with an area of about 3.9 $\times 106 \mathrm{~km}^{2}$. It is a continental overflow basaltic composed of basalts, picritic basalts, concomitant hypabyssal intrusive body. The Estimate of its original volume is: many authors estimate 1 $\times 106 \mathrm{~km}^{3}-2 \times 106 \mathrm{~km}^{3}$ and Courtillot [12] considers the original volume to be as large as $4 \times 106 \mathrm{~km}^{3}$ but currently it is only $4 \times 105 \mathrm{~km}^{3}$. The overflow basalts of the Siberian continent erupted at the $\mathrm{P} / \mathrm{Tr}$ boundary about $251 \mathrm{Ma}$ [13]. Isotopic dating data reveal that lava and intrusive rocks in the Noril'sk area of northern Siberian Cratons (Figure. 1) generally invaded in a very short period of time (less than $1 \mathrm{Ma}$ ), the overall duration of the LIPs is not yet known at all, perhaps as short as 600,000 years [14] and may be much longer than this. A large number of isotopic dating data show that the magmatic activity time of this large igneous province occurred around $250 \mathrm{Ma}$, so it is very likely that the eruption in the entire large igneous province occurs simultaneously [20-21]. Much of the large igneous province is now buried beneath the West Siberian Basin and the Khatanga Geosyncline. The largest lava thickness observed in the Norilsk region is about $3500 \mathrm{~m}$ [22], and the thickness of lava beneath the Katanga Geosyncline may be greater, and drilling reveals that there is also thousands of meters thick concealed basalt beneath the deep-graben structures in the West Siberia Basin [23]. Currently available isotope dating data reveal that the volcanism of the Siberia LIPs began at $254 \mathrm{Ma}$ and ended at $248 \mathrm{Ma}$. Therefore, the duration of the volcanism to $6 \mathrm{Ma}$ [15]. The main eruption of the overflow basalt in the Siberian continent occurred at about $250 \mathrm{Ma}$ with a duration of less than $1 \mathrm{Ma}$ [24].

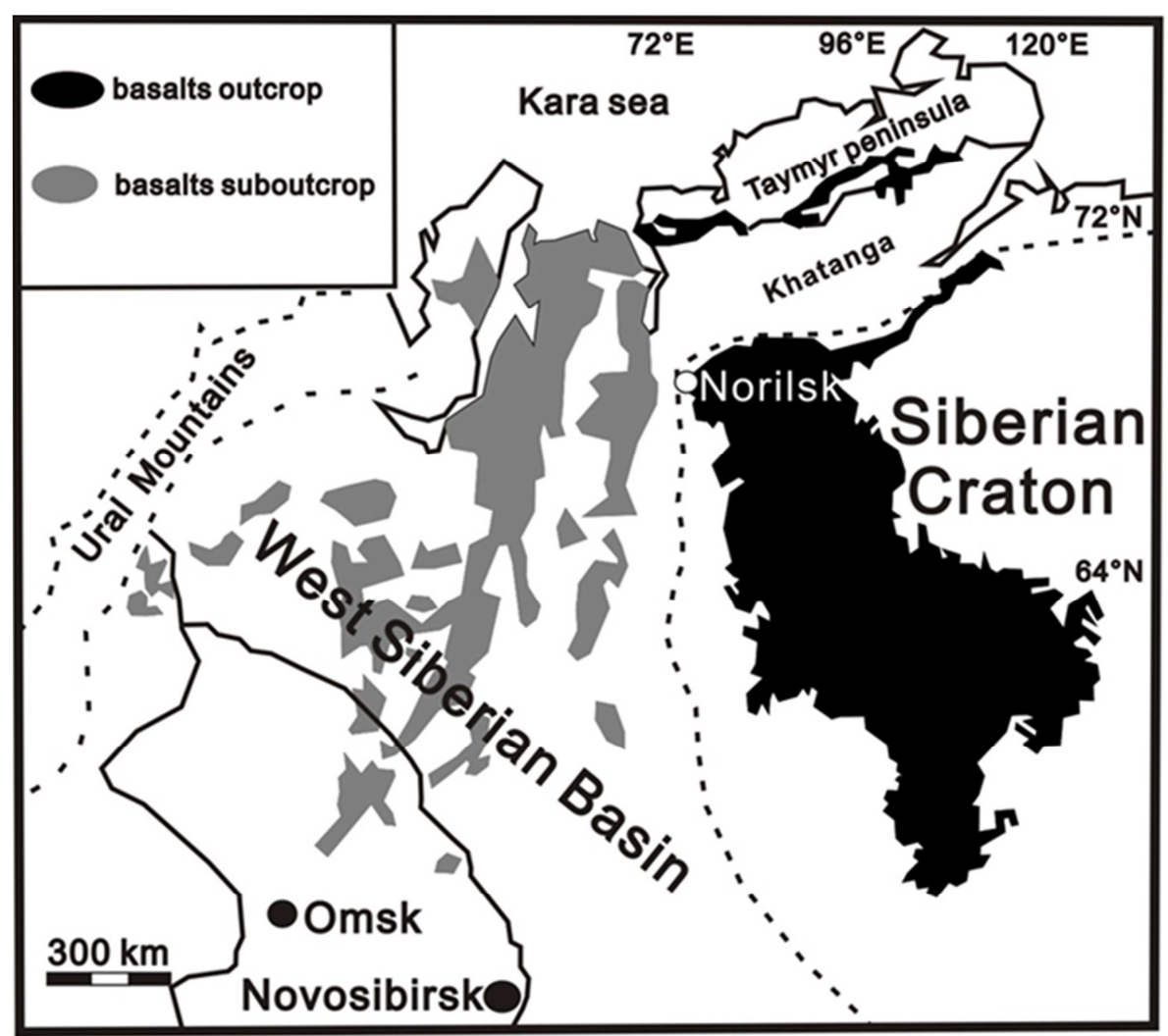

The Figure shows the basalts outcrop on the Siberian Craton and Taimyr Peninsula and the basalts suboutcrop beneath the West Siberian Basin.

Figure 1. Distribution of the Siberian LIPS (Modified) [10, 13, 20, 25]. 
The oldest crustal basement of the Daldyn block of the Archean in the Siberian Craton is about 3.0 Ga [26-27]. The West Siberia basin contains very thick Permian-Triassic volcanics, Triassic continental rocks and Jurassic to Cenozoic continental and marine sedimentary rocks [11]. These volcanic rocks and sedimentary rocks accumulate on a complex base of Proterozoic to Paleozoic sedimentary and crystalline rocks. The basement had been rifted to produce a nearly north-south rift, the rift event has been active for at least the Triassic and may extend to the Jurassic, but the origin is not yet known [25]. Drilling revealed that the majority of volcanic rocks are distributed in the rift graben but some of the volcanic rocks are also produced in the rift wing and thus indicate that at least some of the volcanic activity precedes the rifting event or coincides with the rifting event [13]. Permian-Triassic igneous rocks are mainly composed of basalt, gabbro and a small amount of rhyolite which located beneath the Mesozoic sedimentary rocks. Reichow [19-20] showed that at least some basalts in the West Siberian Basin are the same in age and similar in composition to the continental overflow basalts exposed on the Siberian Craton. Courtillot [24] argues that the West Siberia Basin may have been created by the same event that led to the emplacement of the continental overflow basalts. Although the basin is very deep and huge, but not reach the stage that the mainland was fully cracked and the oceanic crust formed.

\section{A Magmatic Activity Model Based on the Impact of a Celestial Body}

The author put forward that the violent celestial body impact can cause "Collisions Aggregation Effect" and form a large igneous province at the "collisions aggregation point" [4-6]. In Figure 2, the author presents a possible formation model about magmatic activity, volcanic eruption, and LIPs due to the impact. However, not every impact and the "Collisions Aggregation Effect" caused by a celestial body impact can create magmatic activities, volcanic eruptions or LIPs, it may be determined by factors such as the size of the celestial body, the velocity, the direction of the impact velocity vector, and the geographical location of the impact point [7]. Based on previous work, the author consider that the stress state of the plate where the "impact point" or the "collisions aggregation point" located can also affect magmatic activity or the formation of LIPs (Figure 3).

\subsection{A Possible Model}

In Figure 2, the author presents a possible formation model about magmatic activity, volcanic eruption, LIPs and mantle plume due to a impact.
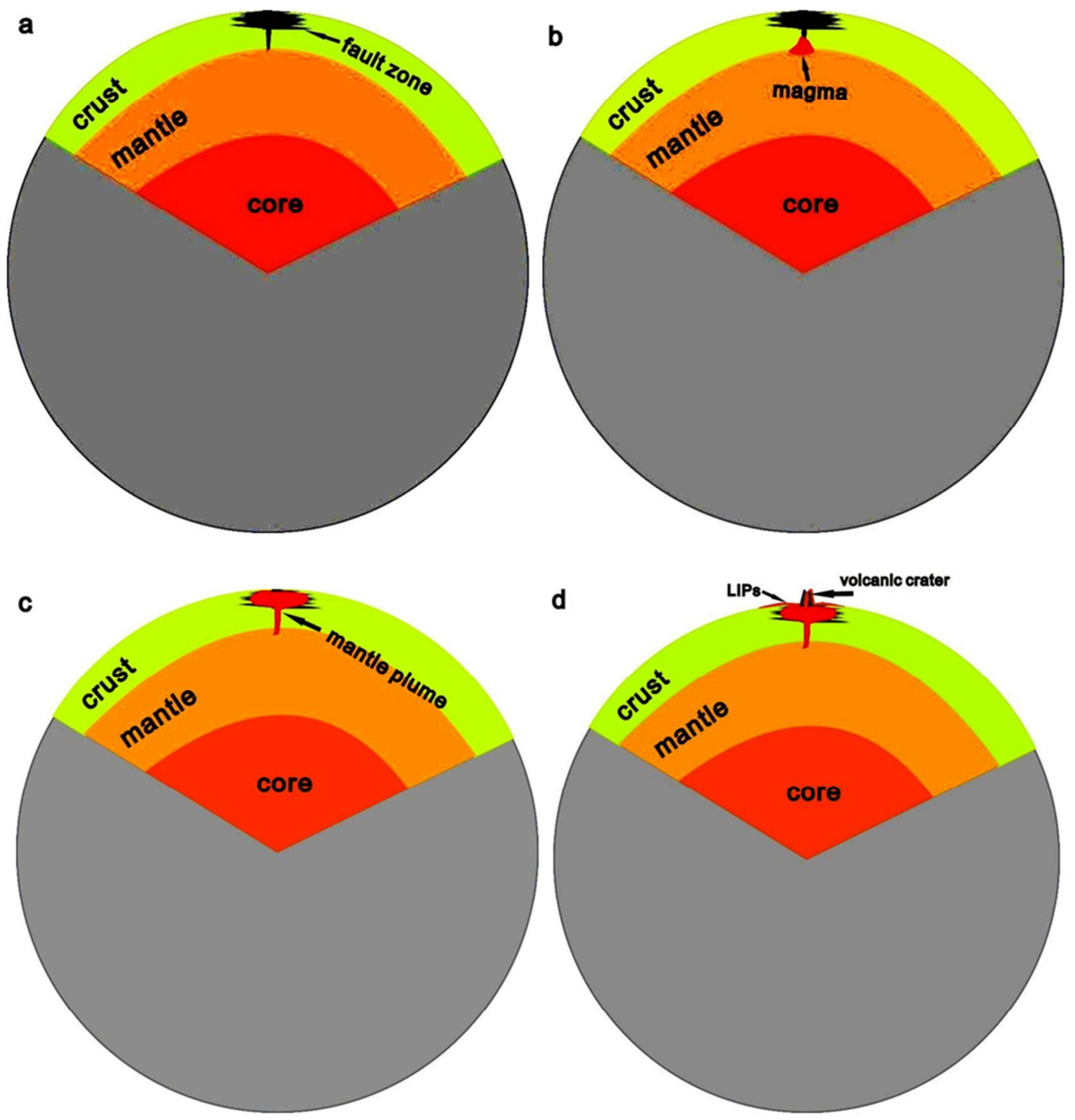

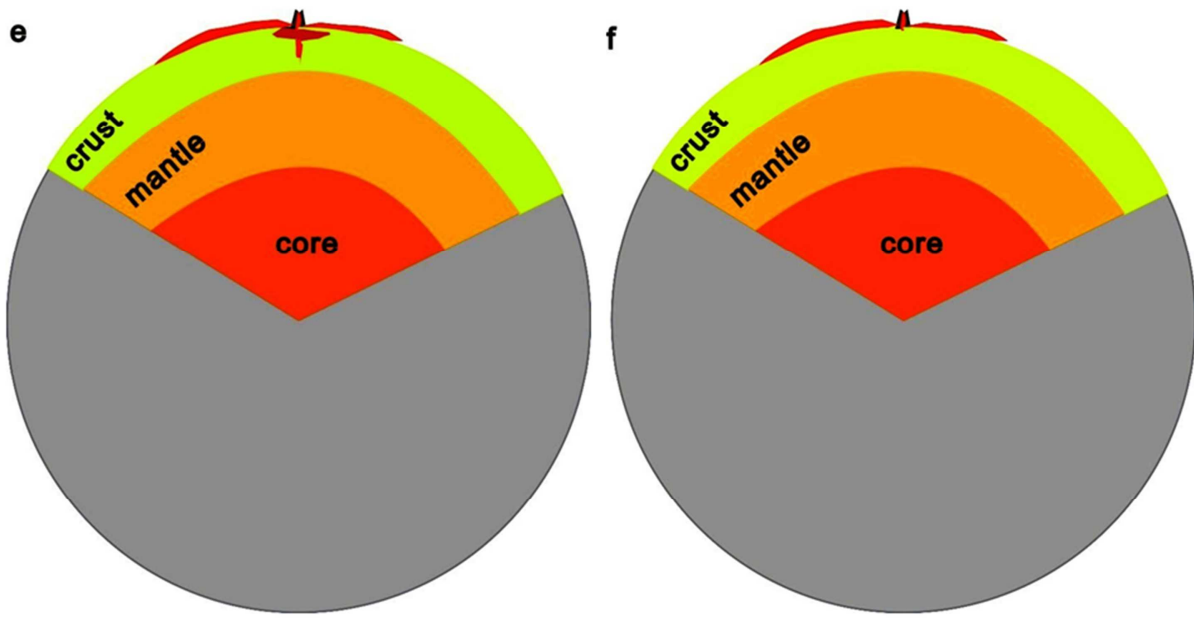

Figure 2. A possible model of a impace.

a. Due to the violent impact of a celestial body, created a tectonic weakness in the crust, even up to the crust-mantle boundary, a fault zone pointing to the Earth's center, and a radial spherical fracture group (Figure 3) at the "impact point" or "collisions aggregation point" [4-7]; b. Because of the tectonic weakness of the crust - mantle boundary, even the fault zone, the magma derived from the mantle intrudes along the structural weak zone under the influence of pressure and may enlarge the invaded channel further; c. A large number of magma invaded and gathered in the radial spherical fracture group, formed a similar head-tail structure of the mantle plume that the head dilated, tail slender deep into the mantle on the longitudinal; d. The magmatic upwelling caused the overlying strata to rise slowly and form a dome. When the excess magma accumulates in the "magma chamber" and exceeds the "threshold" of the overlying rock pressure, volcanic eruptions and magmatic flooding will occur in the fracture system pointing to the Earth's center, and eventually form LIPs; e. After the magma erupted or spilled, the pressure in the magma chamber was reduced and volcanic eruptions or magmatic flooding entered the interim period. When the magma from the mantle once again filled the magma chamber, caused the pressure to rise, the volcanic eruptions or magmatic flooding began again. In this cycle, the surface distributed a large area of overflow magmatic rocks; $f$. The volcanism, magmatism cease, and the magma period ends because of the magma from the mantle is no longer injected into the magma chamber when the the physical or chemical environment of the magma changes in the mantle or the magma intrusion channel is closed.
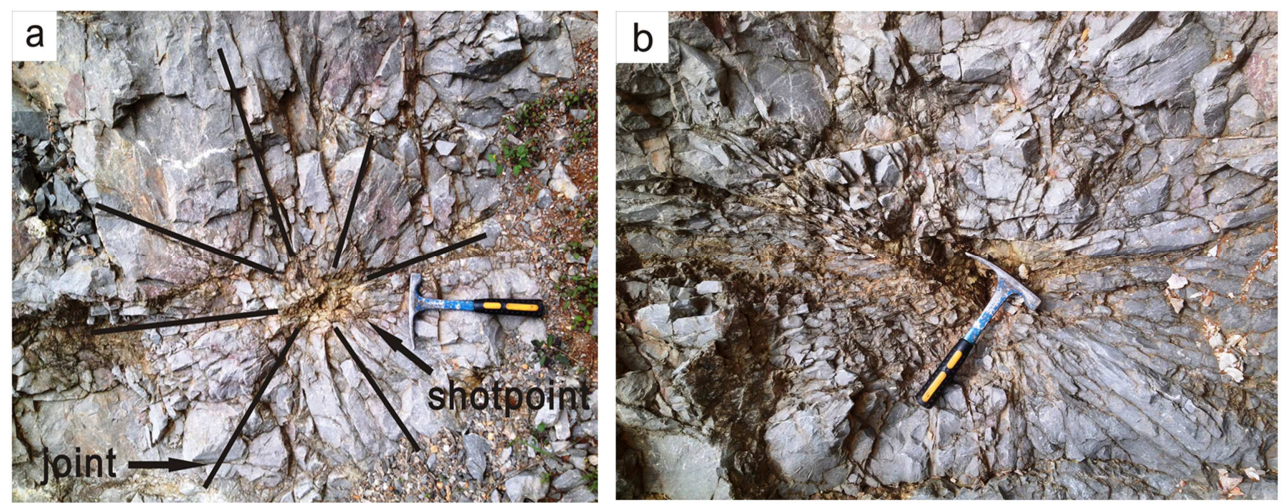

Figure 3. Artificial explosion photo (Taken by author).

Figure $\mathrm{a}, \mathrm{b}$ for the scene photos of a blasting pit form a manual quarry, the shotpoint use borehole explosive filling and detonator detonating. Both $\mathrm{a}$ and $\mathrm{b}$ show a significant radial distribution of joints taking the explosion point as the center. In the three-dimensional direction, you can clearly see the spherical distribution. In combination with field observations, it is clear that these joints are not formed by geological processes, but rather are formed due to the instantaneously release of chemical energy. The length of the hammer is $33 \mathrm{~cm}$ in the Figure.

\subsection{The Influence of Tectonic Stress About Magmatic Activity}

When the "impact point" or "collisions aggregation point" is located in a plate of different stress type, it will affect the formation of volcanic activity or magmatic overflow. In Figure 4, when the "impact point" or "collisions aggregation point" is in a compressive stress plate, the structural weakness or fracture caused by the impact or "Collisions Aggregation Effect" will "heal" and disappear at a certain speed, the channel that the magma invades or migrates shut down, are detrimental to volcanism or magmatic flooding, and will not form LIPs. It is still too late for the magma to accumulate enough pressure, that the channel is closed; While the tensile stress will have no effect on the volcanism or magmatic flooding and may even contribute to its development.

\section{Results}

According to the global paleogeographic maps and data about the Late Permian, the SLIP (point A in Figure 5) is 
located at $60^{\circ} \mathrm{N}, 80^{\circ} \mathrm{E}$ in the Siberian Plateau at the Late Permian (Figure 5) [28-29]; the Falkland Plateau crater (Point D in Figure 5) is located at $70^{\circ} \mathrm{S}, 30^{\circ} \mathrm{E}$ of the southwestern corner of the Gondwanaland in the southernmost point of the South America [18], [28], [30], and the Wilkes Land crater (point E in Figure 5) It may be at $60^{\circ} \mathrm{S}, 110^{\circ} \mathrm{E}[9,28]$. Figure 5 shows the Falkland Plateau crater is in the junction of the Antarctic and South American plates, near the southern orogen of South America [28], and the state may be pressure-type; The Wilkes Land crater is in the eastern Antarctica, close to the Australian plate, not in the orogenic belt, the stress state should not be the pressure type, but is a wide range of ice cover [28]. Figure 6 and 7 show the relationship of the location between the Siberian LIPs and Falkland Plateau crater or Wilkes Land crater does not have a antipodal characteristic, nor have a linear "Collisions Aggregation Effect" profile, but have a nonlinear "Collisions Aggregation Effect" distribution [7], the Falkland Plateau crater correspondence may be better. While whether or not the Falkland Plateau crater or Wilkes Land crater was finally confirmed as a true meteorite crater, their relationships with the Siberian LIPs should have a nonlinear distribution of "Collisions Aggregation Effect" when the time they formed close to the Siberian LIPs, and is the main reason for the formation of the Siberian LIPs. The velocity vector direction of the meteorite impact may have a smaller angle of impact, and significantly eastward (relative to the Earth's center).

a
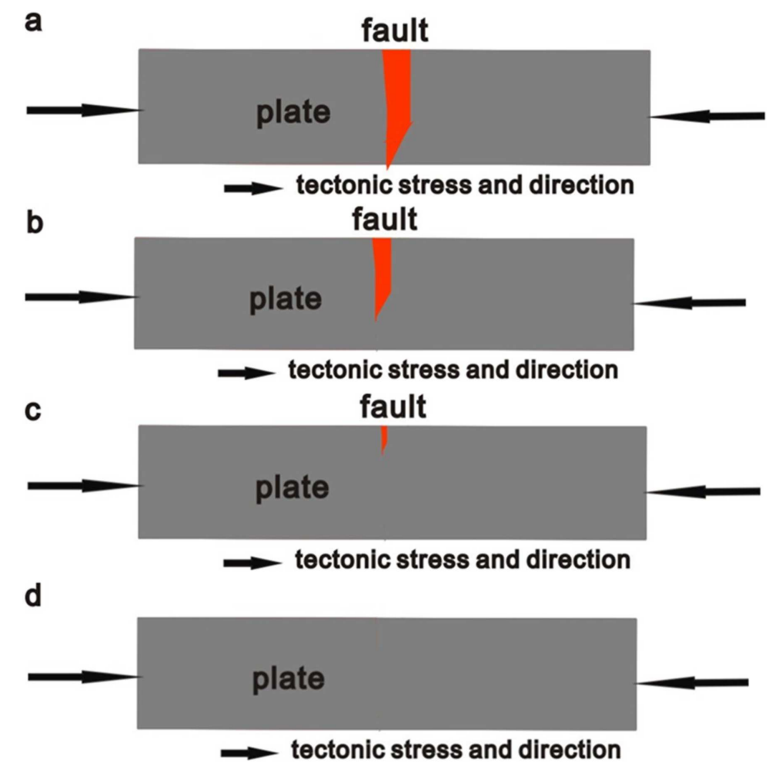

Figure 4. A fracture evolution model for compressively-stressed plate.

a. A meteorite impact on the plate causes a fault zone at the "impact point" or "collisions aggregation point"; $b$. When the "impact point" or "collisions aggregation point" is located in the compressive-stress plate, the fracture system caused by the impact will gradually "heal", may be more obvious in the deep of the fracture system; c-d. When the deep of the fault system completely "heal", the channel that magma invades or migrates is closed.

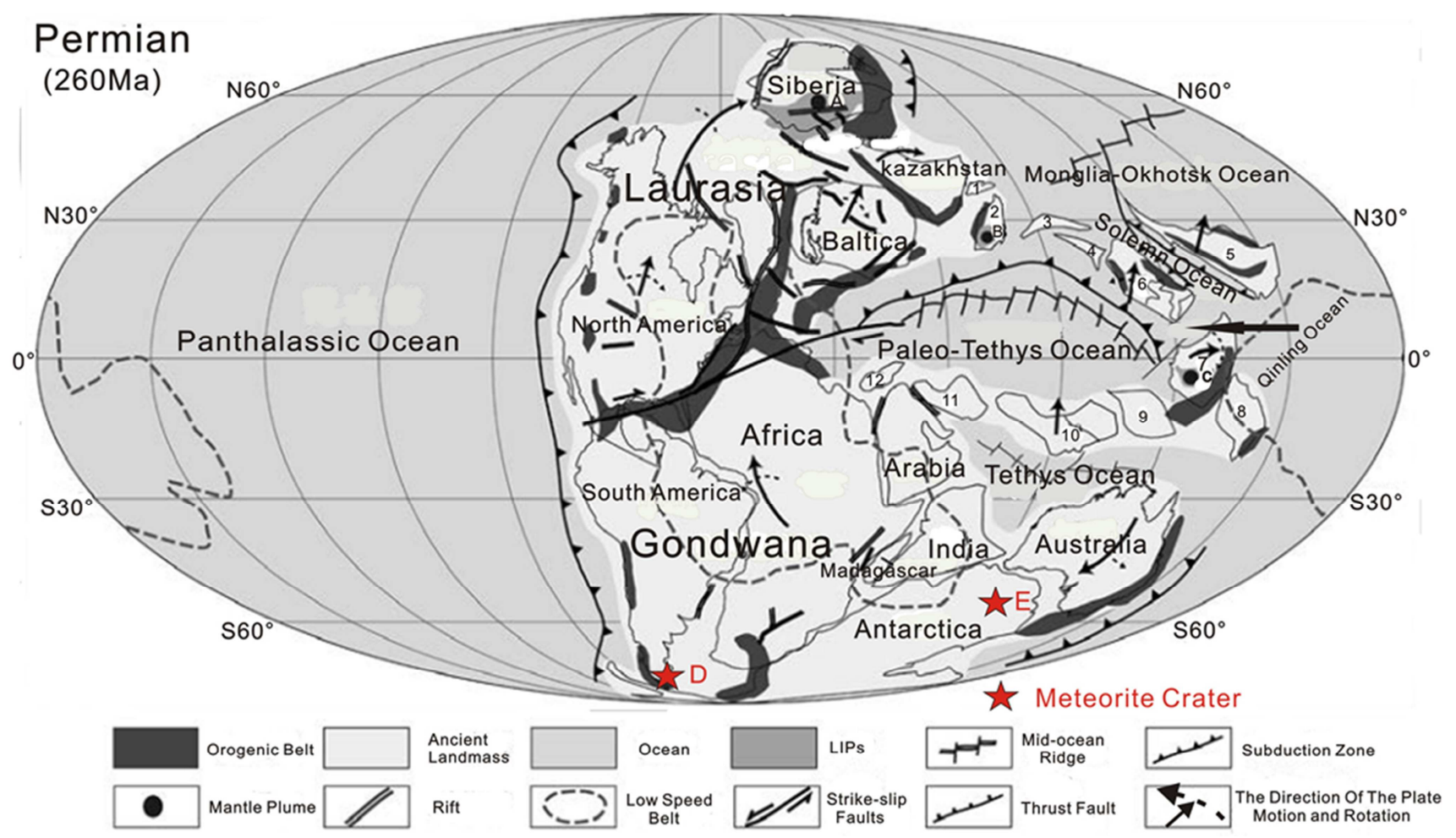

Figure 5. Tectonic Framework of Pangea at about 260Ma [6], [28], [31-36].

1-Junggar; 2-Tarim Block; 3-Qaidam Terrane; 4-Kunlun Terrane; 5-Amuria Block; 6-North China Block; 7-Yangtze (YZ) Block; 8-Kalimantan Plate; 9-Indo-Plate; 10-Malaysia Block; 11-Iranian Plate; 12-Turkey Plates; A-Siberian Mantle Plume (SLIP); B-Tarim Mantle Plume; C-Emeishan Mantle Plume (ELIP); D- Falkland Plateau crater; E-Wilkes Land crater. 


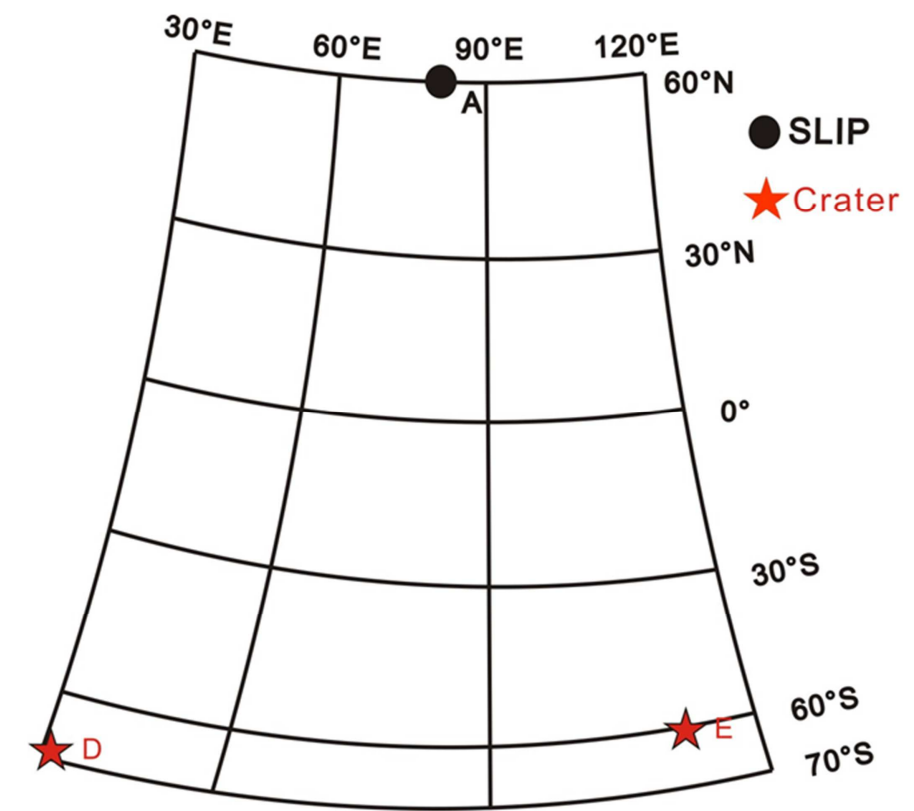

Figure 6. The paleogeographic location of the SLIP, Falkland Plateau crater, Wilkes Land crater.

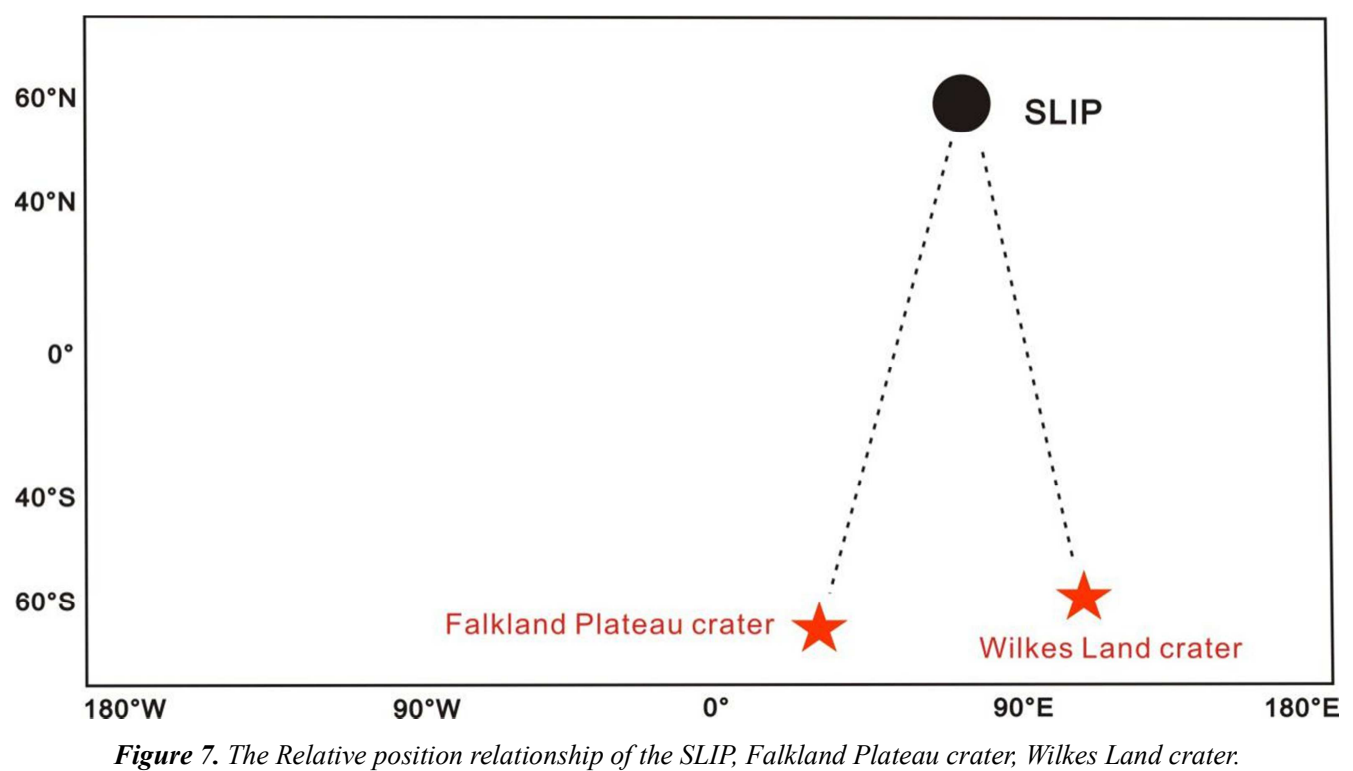

In the Figure 6, 7, the relationship of the location between the Siberian LIPs and Falkland Plateau crater or Wilkes Land crater does not have a antipodal characteristic, nor have a linear "Collisions Aggregation Effect" profile, but have a nonlinear "Collisions Aggregation Effect" distribution [7], the Falkland Plateau crater correspondence may be better. After the comprehensive analysis, consider that the velocity vector direction of the meteorite impact may have a smaller angle of impact, and significantly eastward (relative to the Earth's center).

\section{Discussion}

Based on the above findings, the author believes the following points are worth discussing:

(i). Based on the "Collisions Aggregation Effect", if the "collisions aggregation point" can form LIPs, the "impact point" should also have volcanism, magma overflow or LIPs formation. Taking into account the energy loss form the "impact point" to "collisions aggregation point", the impact will be more obvious and serious influence on the crust, mantle. However, this does not mean that this correspondence relationship will surely appear, it will depend on the geographical locations of the "impact point" and the "collisions aggregation point", the stress characteristics of the plate which the "impact point" and the "collisions aggregation point" located, the size of the meteorite, the impact velocity, the direction of the impact velocity vector and others [7]. In general, if the "impact point" can form LIPs and the "collisions aggregation point" does not necessarily form LIPs; conversely, if there are LIPs at the "collisions aggregation point", the "impact point" should 
form LIPs, which is the diminishing impact energy decides. Based on the above, at the Late Permian, the SLIP is about in the Siberian Plateau at $60^{\circ} \mathrm{N}, 80^{\circ} \mathrm{E}$, the Falkland Plateau crater is located in the southwestern corner of the Gondwana, about $70^{\circ} \mathrm{S}, 30^{\circ} \mathrm{E}$ at the southern tip of the South America, while the Wilkes Land crater may be at $60^{\circ} \mathrm{S}, 110^{\circ} \mathrm{E}$. The location relationship between the Siberian LIPs and the Falkland Plateau crater or Wilkes Land crater does not have a antipodal characteristic, nor have a linear "Collisions Aggregation Effect" profile, but have a nonlinear "Collisions Aggregation Effect" distribution [7], the Falkland Plateau crater correspondence may be better. According to the results, the SLIP as the LIPs of "collisions aggregation point", the "impact point" should have a high probability to develop LIPs. However, no reports of LIPs developed in the Late Permian have been reported in either the Falkland Plateau crater or Wilkes Land crater. The above results show that the Falkland Plateau crater is in the combination zone of the Antarctic and South American plate at the Late Permian, close to the southern orogenic belt of the South America, and the stress state of the crater may be pressure type. This may be one of the reasons why there is no final development of LIPs at the Falkland Plateau crater based on the analysis in Figure 5; The Wilkes Land crater is located in the eastern Antarctica, close to the Australian plate, not in the orogenic belt, and the stress state should not be pressure type, but is in a wide range of ice cover area. When a meteorite falls on an ice cover area with thickness of kilometers (perhaps thicker), its energy is consumed and may cause a wide range of ice to melt, even sea levels rise. However, many reports indicate that the sea level was significantly decreased in the Late Permian [8]. Is the Falkland Plateau crater more likely to be the location of the impace which led to the SLIP?

(ii). With the high-tech detection technology, there may be more and more craters will be found. However, the celestial bodies that form LIPs or cause formation of LIPs should have either: the impact time should be earlier or same as the LIPs; the size should be of a certain size; the "impact point" and the LIPs should have the "Collisions Aggregation Effect" distribution profile;

(iii). It has been reported that about $200 \mathrm{Ma}$ geochronological results were obtained in the mid-Atlantic igneous rocks (CAMP) [37-38], whose main eruption time was significantly later than the meteorite impact event that caused the formation of the SLIP, and whether it is possible that the meteorite impact event that caused the formation of the SLIP is the reason for the formation of the mid-Atlantic igneous rocks (CAMP)? Is the meteorite impact event that caused the formation of the SLIP related to the breakup of the supercontinent Gondwana?

(iv). With regard to the latest developments in research on the Falkland Plateau crater and Wilkes Land crater, the author will continue to monitor and continue discuss.

\section{Conclusion}

Based on the research results of the full text, the author gets the following conclusions and understandings:

(i). The late Permian: the siberian LIPs are in the Siberian plate at $60^{\circ} \mathrm{N}, 80^{\circ} \mathrm{E}$; the Falkland Plateau crater is located in the southwestern corner of the Gondwana, about at $70^{\circ} \mathrm{S}, 30^{\circ}$ $\mathrm{E}$, at the southernmost point of the South American plates, close to the southern orogenic belt of the South America and the stress state of the Falkland Plateau crater may be under pressure; the Wilkes Land crater may be located at $60^{\circ} \mathrm{S}, 110^{\circ}$ $\mathrm{E}$, at the eastern Antarctic continent, close to the Australian plate, is not located in the orogenic belt and the stress state of the Wilkes Land crater should not be pressure-type, but is in a wide range of ice covered area;

(ii). Figure 6 and 7 show the relationship of the location between the Siberian LIPs and Falkland Plateau crater or Wilkes Land crater does not have a antipodal characteristic, nor have a linear "Collisions Aggregation Effect" profile, but have a nonlinear "Collisions Aggregation Effect" distribution, the Falkland Plateau crater correspondence may be better;

(iii). Whether or not the Falkland Plateau crater or Wilkes Land crater was finally confirmed as a true meteorite crater, their relationships with the Siberian LIPs should have a nonlinear distribution of "Collisions Aggregation Effect" when the time they formed close to the Siberian LIPs, and is the main reason for the formation of the Siberian LIPs. The velocity vector direction of the meteorite impact may have a smaller angle of impact, and significantly eastward (relative to the Earth's center);

(iv). About the celestial body which its impact can form LIPs or cause the formation of LIPs, it should have: the impact time should be earlier than LIPs or almost simultaneously; a certain size; the "impact point" and the LIPs distribution area has a "Collisions Aggregation Effect" distribution characteristics;

(v). Figure 2 shows a possible formation model about LIPs of a celestial body collision: due to the violent impact of a celestial body, created a tectonic weakness in the crust, even up to the crust-mantle boundary, a fault zone pointing to the Earth's center, and a radial spherical fracture group at the "impact point" or "collisions aggregation point"; the magma originating from the mantle intrude along the weak zone under pressure, a large number of magma invaded and gathered in the radial spherical fracture group, causing the overlying strata rising slowly, forming a dome and a similar head-tail structure of the mantle plume that the head dilated, tail slender deep into the mantle on the longitudinal. When excessive magma is accumulated in the "magma chamber" and exceeds the "threshold" of the overlying rock pressure, volcanic eruptions and magmatic flooding occur on the fracture system pointing to the Earth's center and eventually form LIPs. After that, the magma chamber pressure was reduced and the volcanic eruption or magmatic flooding entered the interim period. When the magma from the mantle once again filled the magma chamber, caused the pressure to rise in the magma chamber, the volcanic eruption or magmatic flooding began again. In this cycle, large-area overflow magmatic rocks were distributed on the ground. The volcanism, magmatism cease, and the magma period 
ends because of the magma from the mantle is no longer injected into the magma chamber when the the physical or chemical environment of the magma changes in the mantle or the magma intrusion channel is closed;

(vi). Figure 3 shows that when the "impact point" or "collisions aggregation point" is in the compressional plate, the weak zones or faults caused by the impact or "Collisions Aggregation Effect" will" heal "and disappear at a certain speed, and the magma is still too late to accumulate enough pressure to invade the magma that the passage to be transported has been closed, while tension stress has no effect on volcanism or magmatism and may even contribute to it;

(vii). The author will continue to pay attention to the latest research progress on the Falkland Plateau crater and Wilkes Land crater, and will continue to discuss.

\section{Acknowledgements}

I thank Dr. Li Yanli for her firm support for finding evidence and paleogeographical maps. Also thanks to Professor Zuo Qionghua and Yang Xiaofeng for my research support. Thanks also to the Science and Technology Innovation Fund of the Yunnan Provincial Bureau of Geology and Mineral Resources for my tremendous help.

\section{References}

[1] Hartmann, W. K. 1965. Terrestrial and lunar flux of large meteorites in the last two billion years. Icarus, 4 (2):157-165.

[2] https://en.wikipedia.org/wiki/Vredefort_crater.

[3] https://en.wikipedia.org/wiki/2007_Carancas_impact_event.

[4] LIU Chenming, YANG Demin, MA Shaochun. 2015. New ideas on the genesis of Emeishan basalt-the effect of collision and coalescence caused by the collision of celestial objects. Mineral Resources And Geology, 29 (5):585-590. (in Chinese with English abstract).

[5] Liu Chenming. 2018. The New Hypothesis of the Origin to the Emeishan LIP: Because of the "Collisions Aggregation Effect" of a Meteorite Impact. Earth Sciences. Vol. 7, No. 1, pp. 34-41. doi: 10.11648/j.earth.20180701.16.

[6] Liu Chenming, Yang Demin. 2018. Research on Paleogeography Recovery of "Impact Point" Based on "Collisions Aggregation Effect". Earth Sciences. Vol. 7, No. 2, pp. 58-63. doi: 10.11648/j.earth.20180702.13.

[7] Liu Chenming, Yang Demin. 2018. Study on the Relationship Between Deccan LIPs and Chicxulub Crater Based on "Collisions Aggregation Effect". Earth Sciences. Vol. 7, No. 2, pp. 64-73. doi: 10.11648/j.earth.20180702.14

[8] Rong J Y, Huang B. 2014. Study of Mass Extinction over the past thirty years: A synopsis. Scientia Sinica Terrae, 44: 377 404. (in Chinese).

[9] von Frese, R. R. B., L. V. Potts, S. B. Wells, T. E. Leftwich, H. R. Kim, J. W. Kim, A. V. Golynsky, O. Hernandez, and L. R. Gaya-Pique'. 2009. GRACE gravity evidence for an impact basin in Wilkes Land, Antarctica . Geochem. Geophys. Geosyst., 10, Q02014, doi:10.1029/2008GC002149.
[10] XIA Lin-qi, XU Xue-yi et al. 2012. Comparison of Three Large Igneous Provinces (Emeishan, Siberia, Deccan) in Asia. NORTHWESTERN GEOLOGY. 45 (2):1-26. (in Chinese with English abstract).

[11] Reiehow, M. K., Saunders, A. D., White, R. V., Al'Mukhamedov, A. I., Medvedev, A. Ya. 2005. Geochemistry and petrogenesis of basalts from the West Siberian Basin: an extension of the Permo-Triassic Siberian Traps, Russia. Lithos. 79:425-452.

[12] Courtillot, V. E., Jaupart. C., Manighetti, I., Tapponnier, P., Besse, J. 1999. On causal links between flood basalts and continental breakup. Earth and Planetary Science Letters. 166:177-195.

[13] Saunders, A. D., Jones, S. M., Morgan, L. A., Pierre, K. L., Widdowson, M., Xu, Y. G. 2007. Regional uplift associated with continental large igneous provinces: The role of mantle plumes and the lithosphere. Chemical Geology. 241:282-318.

[14] Campbell, I. H., Griffiths, R. W. 1992. The changing nature of the mantle hotspots through time: implication for the geochemical evolution of the mantle. Journal of Geology. 92:497-523

[15] Bryan, S. E., Ernst, R. E. 2008. Revised definition of large igneous provinces (LIPs). Earth-Science Reviews. 86:175-202.

[16] Bentley CR. No giant meteorite crater in Wilkes Land, Antarctica. Journal of Geophysical Research. 1979, 84 (Sept. 10): 5681-5682.doi:10.1029/JB084iB10p05681.

[17] Barker, P. F. 1999. Evidence for a volcanic rifted margin and oceanic crustal structure for the Falkland Plateau Basin. Journal of the Geological Society, 156 (5). 889-900. https://doi.org/10.1144/gsjgs.156.5.0889.

[18] Rocca MCL, Rampino MR, Báez Presser JL. 2017. Geophysical evidence for a large impact structure on the Falkland (Malvinas) Plateau. Terra Nova. 00:1-5. https://doi.org/10.1111/ter.12269.

[19] Reiehow, M. K., Saunders, A. D., White, R. V., Pringle, M. S., Al'Mukhamedov, A. I., Medvedev, A. L., Korda, N. 2002. New ${ }^{40} \mathrm{Ar}-{ }^{39} \mathrm{Ar}$ data on basalts from the West Siberian Basin: extent of the Siberian flood basalt province doubled. Science. 296:1846-1849.

[20] Reiehow, M. K., Saunders, A. D., White, R. V., Al'Mukhamedov, A. I., Medvedev, A. Ya. 2005. Geochemistry and petrogenesis of basalts from the West Siberian Basin: an extension of the Permo-Triassic Siberian Traps, Russia. Lithos. 79:425-452.

[21] Kamo, S. L., Czamanske, G. k., Amelin, Y., Fedorenko, A., Davis, D. W., Trofimov, V. R. 2003. Rapid eruption of Siberian flood-volcanic rocks and evidence for coincidence with the Permian-Triassic boundary and mass extinction at $251 \mathrm{Ma}$. Earth and Planetary science Letters. 214:75-91.

[22] Wooden, J. L., Czamanske, G. K., Fedorenko, V. A., Arndt, N. T., Chauvel, C., Bouse, R. M., King, B. W., Knight, R. J., Siems, D. F. 1993. Isotopic and trace-element constraints on mantle and crustal contributions to Siberian continental flood basalts, Noril' sk area, Siberia. Geochim et Cosmochim Acta. 57:3677-3704.

[23] Westphal, M., Gurevitch, E. L. Samsonov, B. V., Feinberg, H., Pozzi. J. P. 1998. Magnetostratigraphy of the lower Triassic volcanics from deep drill SG6 in western Siberia: evidence for long-lasting Permo-Triassic volcanic activity. Geophysical Journal International. 134:254-266. 
[24] Courtiliot. V. E., Renne, P. R. 2003. On the ages of flood basalt events. Comptes Rendus Geoscience. 335:113-140.

[25] Saunders, A. D., England, R. W., Reichow. M. K., White, R. V. 2005. A mantle plume origin for the Siberian Traps: uplift and extension in the West Siberian Basin, Russia. Lithos. 79:407-424.

[26] Griffin. W. L., Ryan, C. G., Kaminsky, F. V., O, Reilly, S. Y. 1999. The Siberian lithosphere traverse: mantle terranes and the assembly of the Siberrian Craton. Tectonophysics. 310: $1-35$.

[27] Griffin. W. L., Spetsius, Z. V., Pearson, N. J., O, Reilly, S. Y. 2002. In situ Re-Os analysis of sulfide inclusions in kimberlitic olivine: new constraints on depletion events in the Siberian lithospheric mantle. Geochemistry, Geophysics, Geosystems. 3. doi: $10.1029 / 2001 \mathrm{GC} 000287$.

[28] Li Weibo, Li Jianghai, Wang Honghao, et al. Characteristics of the reconstruction of Permian paleoplate and lithofacies paleogeography. Geology in China, 2015, 42 (2): 685-694 (in Chinese with English abstract).

[29] WAN Tianfeng, ZHU Hong. 2007. Positions and Kinematics of Chinese Continental Blocks in Reconstruction of Global Paleo-continents for Paleozoic and Triassic. Geoscience. 21 (1):1-13. (in Chinese with English abstract).

[30] Luciano Alessandretti, Lucas Veríssimo Warren, Mario Luis Assine, Rômulo Machado, Cristiano Lana. 2016. Reply to the comments on: "From source-to-sink: The Late Permian SW gondwana paleogeography and sedimentary dispersion unraveled by a multi-proxy analysis". Journal of South American earth sciences. 70:368-382.

[31] Scotese C R. 2002. Paleomap website: http://www.scotese.com, chris@scotese.com.

[32] Torsvik T H, Steinberger B, Cocks L B M, et al. 2008. Longitude:Linking Earth's ancient surface to its deep interior. Earth and Planetary Science Letters, 276: 273-282.

[33] Golonka J. 2011. Chapter 6 Phanerozoic palaeoenvironment and palaeolithofacies maps of the Arctic region $[\mathrm{C}] / /$ Spencer A M, Embry A, Gautier D L A, et al. Arctic Petroleum Geology, London Geological Society of London, 35: 79-129.

[34] Courtillot V, Davaille A, Besse J, et al. 2003. Three distinct types of hotspots in the Earth' s mantle. Earth and Planetary Science Letters, 205 (3): 295-308.

[35] Nikishin A M, Zieglerb P A, Stephenson R A, et al. 1996. Late Precambrian to Triassic history of the East European Craton:dynamics of sedimentary basin evolution. Tectonophysics, 268: 23-63.

[36] Kuzmin M I, Yarmolyuk V V, Kravchinsky V A. 2010. Phanerozoic hotspot traces and paleogeographic reconstructions of the Siberian continent based on interaction with the African large low shear velocity province. Earth-Science Reviews, 102: 29-59.

[37] Condie K C. 2001. Mantle Plumes and Their Records in Earth History. Cambridge University Press, 306.

[38] Blackburn, T. J., Olsen, P. E., Bowring, S. A., McLean, N. M., Kent, D. V., Puffer, J., McHone, G., Rasbury, E. T., Et-Touhami, M., 2013. Zircon U-Pb Geochronology Links the End-Triassic Extinction with the Central Atlantic Magmatic Province. Science. 340:941-945.

\section{Biography}

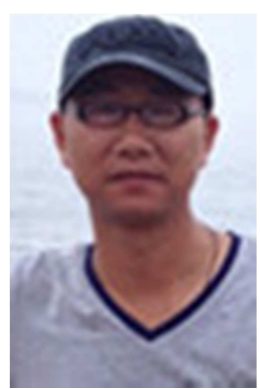

Liu Chenming (1984-), master, assistant professor, mainly engaged in teaching and research work, research directions are: metallogenic regularity and metallogenic prediction, mineralogy, large igneous province (LIPs). The Papers from yunnan province bureau of geology and mineral resources of science and technology innovation fund, Fund number: 2016JJ02. 